\title{
Critical Thinking Skills of Junior High School Students' Based Local Potentian of Making Kempul/Gong Reyog Ponorogo
}

\author{
Aisyah Nurul Janah ${ }^{1, *}$ Pujianto $^{2}$ \\ ${ }^{1}$ Master of Natural Science Education, Faculty of Mathematics and Natural Sciences, Universitas Negeri \\ Yogyakarta, Indonesia \\ ${ }^{2}$ Departement of Natural Science Education, Faculty of Mathematics and Natural Sciences, Universitas Negeri \\ Yogyakarta, Indonesia \\ ${ }^{*}$ Corresponding author. Email: aisyahnurul.2019@student.uny.ac.id
}

\begin{abstract}
The purpose of this study was to determine the critical thinking skills of junior high school students based on local potential about making Kempul/gong Reyog. The study used a survey method with a purposive sampling technique for sampling. The research subjects were 103 students from Junior High School in Ponorogo. The research instrument developed by authors according the indicator of critical thinking skills based on local potential about making kempul/gong Reyog in Ponorogo, and validated by experts. Data obtained from the score answered questions using an assessment rubric for each item. The data analysis in this study used quantitative descriptive. The analysis results show that students' critical thinking skills on indicatorsa simple explanation 46\%, linking 32\%, comparing and differentiating $45 \%$, analysis, and evaluation $34 \%$, skills in making and conveying conclusions $30 \%$. The result the critical thinking skills based on local potential learners about making kempul/gong Reyog are very low category. The survey instrument was developed by authors according the indicator of critical thinking skills form questions.
\end{abstract}

Keywords: Critical thinking skills, Making kempul/gong Reyog, Local potential.

\section{INTRODUCTION}

Science learning must follow the development of a predetermined curriculum. Indonesia is currently implementing the Curriculum 2013, which integrates interrelated attitudes, skills, and knowledge to create creative, productive, and innovative output that can compete in the 21 st century. There are $21^{\text {st }}$ Century skills covering four aspects which is known as $4 \mathrm{C}$ for creativity, communication, collaboration, and critical thinking [1]. Critical thinking skills are a thinking model that aims to improve structured thinking skills [2]. Thinking skills in all fields of science can be supported by critical thinking skills [3]. Because, with critical thinking skills, students are required to interpret and analyze the information obtained [4].

This survey research's critical thinking skills include five aspects: providing simple explanations, connecting, comparing and contrasting skills, analyzing, and evaluating, and making and conveying conclusions. Learning to think critically is very important for modern education today, and the rapid development to equip students with sufficient competence in solving problems in everyday life [5]. Critical thinking skills can used to obtain several sources for making evidence-based decisions, so as to develop other skills needed [6]. Aspects and indicators [7] shown in table 1.

Table 1. Aspects and indicators of critical thinking skills

\begin{tabular}{|c|c|}
\hline Aspects & Indicators \\
\hline \multirow{3}{*}{$\begin{array}{l}\text { Give a simple } \\
\text { explanation }\end{array}$} & Identify problems \\
\hline & $\begin{array}{l}\text { Research for various sources of } \\
\text { relevant information }\end{array}$ \\
\hline & $\begin{array}{l}\text { Explain the problem based on } \\
\text { the information data }\end{array}$ \\
\hline Linking skills & Sort and link the information \\
\hline
\end{tabular}




\begin{tabular}{|l|l|}
\hline \multicolumn{1}{|c|}{ Aspects } & \multicolumn{1}{c|}{ Indicators } \\
\hline $\begin{array}{l}\text { Compare and } \\
\text { contrast }\end{array}$ & $\begin{array}{l}\text { Compare and contrast the } \\
\text { information and classify }\end{array}$ \\
\hline $\begin{array}{l}\text { Analysis and } \\
\text { evaluation }\end{array}$ & \begin{tabular}{l} 
Analyze existing information \\
\cline { 2 - 2 }
\end{tabular} \\
\hline analysis that has been done \\
\hline $\begin{array}{l}\text { Make and convey } \\
\text { conclusions }\end{array}$ & $\begin{array}{l}\text { Make and convey conclusions } \\
\text { based on analysis and evaluation }\end{array}$ \\
\hline
\end{tabular}

Learning Science in Junior High School is by finding out about nature, not only about knowledge in the form of facts, concepts and principles. The discovery process in everyday life that is closer to students will be more meaningful, and the level of concentration of students is more focused.

Local potential-based learning can teach concepts that can be related to the surrounding environment, that science learning is closer to the phenomenon as a whole and meaningful. [8] Science has four dimensions, namely science as a way of thinking, as a process (science as a way of investigating), as a product (science as a body of knowledge), and applications (science and its interaction with technology and society). These overall dimensions support each other in shaping the thinking patterns and behavior of students in science. Teaching using science, technology, and society approach direct students to care more about their environment [9].

The general characteristics of local potential are found in the community. The community feels they have it and is a hereditary win. The local potential referred to in this study is the manufacture of gong in Ponorogo. Gong is one of the instruments of a gamelan set. Gamelan is a set of typical Indonesian musical instruments. This instrument (tool) has developed for a long time ago until now. Most of the people in Ponorogo, to be precise in Paju village, are engaged in gong artisans, which are developed into regional potentials. However, the existence of this potential will slowly disappear if it is not introduced to the community early on. One of the efforts to introduce present raise teaches it is through educational facilities in learning at school.

Science reveals natural phenomena and their symptoms, which are very strategic for educational media. Natural science learning based on local potential that characterizes this area can lead students to use critical thinking skills. Students will be more active, critical, and analytical in solving problems. Because critical thinking skills are influential in academic success and success in the future.

\section{RESEARCH METHOD}

A descriptive qualitative survey was utilized to achieve the aim of this study. The target sample was junior high school student in Ponorogo with purposive sampling technique. A total 103 students took a part in the study. The survey instrument was developed by authors according the indicator of critical thinking skills form questions based on local potential about making kempul/ gong Reyog in Ponorogo.

The eight item number of questions developed from indicators of critical thinking skills, which consist of studying/identifying problems, looking for various relevant sources of information, explaining the problem simply based on the information data obtained, sorting and connecting the information obtained, comparing and differentiating the information obtained. Classifying it, analyzing existing information, re-evaluating the results of the analysis that has been done, and making and conveying conclusions based on analysis and evaluation. The data were obtained from the critical thinking skills test answer scores of students who used an assessment rubric for each question item. The data analysis technique in this research is to change the score obtained into a percentage using the below formula:

$\mathrm{X}=\frac{\sum \mathrm{St}}{\mathrm{S}} \times 100 \%$

$\mathrm{X}$ as percentage scores, $\sum \mathrm{St}$ is the number of scores obtained and $\mathrm{S}$ is the maximum score. Quantitative data in the form of a percentage of the score was converted into qualitative data according to the criteria [10] in Table 2.

Table 2. Percentage of Students' Critical Thinking Skills Criteria

\begin{tabular}{|l|l|c|c|}
\hline No & Percentage (\%) & Grade & Criteria \\
\hline 1. & $86-100$ & A & Very High \\
\hline 2. & $76-85$ & B & High \\
\hline 3. & $66-75$ & C & Medium \\
\hline 4. & $55-65$ & D & Low \\
\hline 5. & $\leq 54$ & E & Very Low \\
\hline
\end{tabular}

\section{RESULT AND DISCUSSION}

This research to determine students' critical thinking skills aboutmaking kempul/gong Reyog in Ponorogo, which is one of the local potentials. The local potential is one of the regional potentials, including natural resources, human resources, geography, and culture [11], [12] which can be used as 
learning resources. Local potentials that exist around students can be used as a whole and complete learning theme [13], [14] so that it can be applied in everyday life.

There are five indicators of critical thinking skills students, namely providing simple explanations, connecting, comparing and differentiating skills, analysis and evaluation, and making and conveying conclusions. The instrument for measuring students' critical thinking skills in the form of essay questions consisting of eight items. Each question represents each indicator of critical thinking skills related to the local potential for making kempul/ gong Reyog Ponorogo. Learning critical is a process that makes students more active, where students think about things in more depth to ask questions, find relevant information [15].

The result analysis of the integrated critical thinking skills test based on local potential of making kempul/gong Reyog in this study can be seen in Figure 1 .

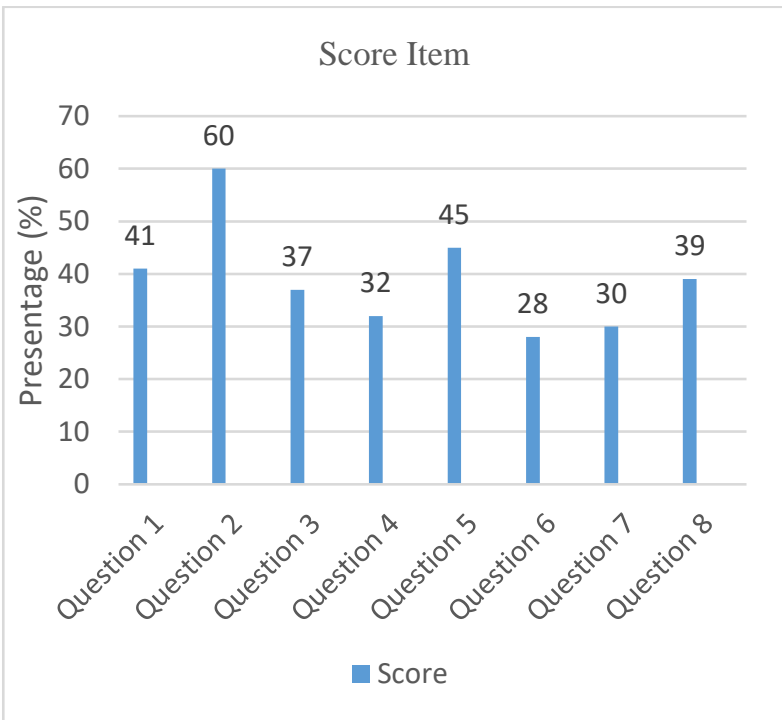

Figure 1 Results of critical thinking skills analysis based local potential making kempul/gong reyog ponorogo

Figure 1 shows the percentage of students' score acquisition for each question item. The analysis results show that the thing with the highest achievement is in question two, about providing a simple explanation, which is $60 \%$. Students can present a simple explanation in accordance with existing sources around them. Local potential-based learning themes are more attractive to students related to daily life [16]. At some times, the lowest score is about six, namely $28 \%$. Many students have difficulty even completing the wrong problem in six. The low achievement in question six about analysis and evaluation indicates that in learning, the ability to analyze and evaluate is still lacking. Students have not been able to connect cause and effect based on relevant sources. Students can think critically by thinking deeply and logically to obtain and evaluate evidence empirically as a result of learning [17].

Figure 2 shows students' critical thinking skills in the first aspect, namely providing a simple explanation. The percentage of results obtained is $46 \%$, indicating that local potential makes Kempul/gong students' integrated critical thinking skills provide explanations that are still very low or very lacking. Students do not understand so it is difficult to explain reasons. This can be seen from the answers given by students

Linking skills, which are indicators of critical thinking skills also relatively low. This can be seen from the percentage of students' answers by $32 \%$. It can be seen that students do not know and understand so that skills in connecting are still difficult. Students cannot find a conceptual relationship because of the lack of analytical skills correctly [18]. The percentage of students' skills in comparing and differentiating was $45 \%$. This shows that it is in the very low category. Students are still lacking in the concepts presented so that students have difficulty comparing and differentiating. The fourth indicator, namely analysis, and evaluation are very low, which shows a percentage of $34 \%$. Students' answers show that the ability to analyze and evaluate is still limited or not too deep. Students' skills in making and conveying conclusions obtained a percentage of $30 \%$, which indicates that they are in a very low category. From the students' answers, it can be seen that the ability to make conclusions is still limited. They do not dig deeper based on their analysis. Critical thinking is related to making complex decisions in all situations [19].

Aspect of Critical Thinking Skills (\%)

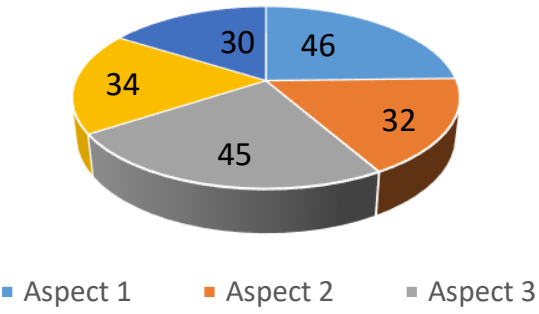

Figure 2 Results of critical thinking ability analysis integrated local potential making kempul/gong reyog ponorogo 
The average results of students 'critical thinking skills are shown in Table 3. The results of the average analysis tests for all indicators is to provide simple explanations, skills to connect, compare and differentiate, analysis and evaluation, and making and conveying conclusions obtained a percentage of $37.00 \%$, which is included in the very low category. This is consistent with PISA results in 2015 [20] which showed that students' high-level thinking was still low. The low achievement of students' critical thinking skills based on local potential shows that students are less capable of critical thinking skills so that every indicator has not been met.

The learning process must involve students to practice skills, teachers are required to use appropriate learning methods to train students' critical thinking skills [21]. Skills are a priority in learning objectives, so that students must be trained in skills in every lesson. Students must be trained to think critically during the learning process with the right strategy, so that students' critical thinking skills will develop [22]. One that affects critical thinking skills is a learning strategy [23]. In addition, students' critical thinking skills are influenced by the learning experience during the learning process [24].
Critical thinking skills are the main goal of learning [32] in accordance with the formulation of 16 learning principles according to the Indonesian National Education Standards Agency [33], which must be met in the 21 st-century education process. Critical thinking skills are very influential in success and success in the future [34].

\section{CONCUSLION}

The findings suggest that students have very low level of critical thinking skills based local potential of making kempul/gong reyog Ponorogo. Innovation toward learning material are the key to aid students' critical thinking skills. Additionally, teacher need to improve their competencies of making interesting learning source that integrated with potential local can engage student critical thinking skills.

\section{AUTHORS' CONTRIBUTIONS}

The first author contributed to the conception and design of study and the second author validates the result.

Table 3. The average critical thinking skills

\begin{tabular}{|c|l|c|c|}
\hline No & \multicolumn{1}{|c|}{ Indicators } & Percentage (\%) & Mean of Percentage (\%) \\
\hline 1 & Give a simple explanation & 46 & \\
\hline 2 & Linking skills & 32 & \multirow{2}{*}{37.4} \\
\hline 3 & Compare and contrast & 34 & \\
\hline 4 & Analysis and evaluation & 30 & \\
\hline 5 & Mae and convey conclusions & \\
\hline
\end{tabular}

Critical thinking skills can encourage students to think independently [25] to find knowledge through experience [26], [27]. Critical thinking is a form of metacognitive knowledge which includes thinking about declarative knowledge. Low test results can be caused by other factors, such as an inaccurate learning process [28]. The learning process must train students to think critically [29]. Learning activities with the environment are still limited so that critical thinking skills cannot develop [30]. Training activities are very important for students' critical thinking skills according to the 21st century. [31] Show that critical thinking strategies are not developed or practiced extensively during primary and secondary education. Therefore, teachers are obliged to help students develop the skills necessary to synthesize a modern and complex society.

\section{ACKNOWLEDGMENTS}

Thanks to the students who participated in the research.

\section{REFERENCES}

[1] National Education Association, 21st Century Skills, Deel Press, 2002.

[2] A. Fisher, Introduction to Critical Thinking, Erlangga, 2009.

[3] OCR, Specification AS/A Level Critical Thinking, OCR Recognising Achievement, 2013.

[4] I. Suto, 21st Century skills: Ancient, Ubiquitous, Enigmatic?, University of Cambridge, 2013. 
[5] K.Y. Ku, Assessing Students' Critical Thinking Performance: Urging for Measurements using Multi-Response Format Thinking Skills and Creativity 4, Thinking Skills and Creativity, 4(1) (2009) 70-76. DOI: https://doi.org/10.1016/j.tsc.2009.02.001

[6] E.R. Lai, M. Viering, Assessing 21st Century Skills: Integrating Research Findings, National Council on Measurement in Education, 2012.

[7] P.A. Facione, Critical Thinking: What it is and Why It Counts. Insight Assessment, California Academic Press, 2015.

[8] E.L. Chiappetta, T.R. Koballa, Science Instruction in The Middle and Secondary School: Seventh Edition, Pearson Education, 2010.

[9] A.A. Carin, R.B. Sund, Teaching Modern Science Third Edition, Charles E. Merril Publishing Company, 1989.

[10] N. Purwanto, Principles of Learning Evaluation Techniques, Bandung, Rosdakarya, 2002.

[11] A. Anisa, Improving Students' Critical Thinking Skill through Science Teaching Based on Jepara's Local Potential, Jurnal Inovasi Pendidikan IPA (3) (2017) 1-11. DOI: https://doi.org/ 10.21831/jipi.v3i1.8607

[12] R.P. Situmorang, Analysis of Local Potential for Developing Teaching Materials Biology in Senior High School 2 Wonosari, Jurnal Pendidikan Sains 4(1) (2016) 51-57.

[13] I.P.M. Dewi, I.G.P. Suryadarma, I. Wilujeng, S. Wahyuningsih, The Effect of Science Learning Integrated with Local Potential of Wood Carving and Pottery towards The Junior High School Students' Critical Thinking Skills, Jurnal Pendidikan IPA Indonesia 6(1) (2017) 103-109. DOI: https://doi.org/10.15294/jpii.v6i1.9598

[14] W. Insih, Z.K. Prasetyo, S.I.G. Putu, Science learning based on local potential: overview of the nature of science (NoS), in: AIP Conference Proceeding, vol. 1868, American Institute of Physics, Maryland, 2017, pp. 1-7, DOI: https://doi.org/10.1063/1.4995189

[15] A. Fisher, Introduction to Critical Thinking, Erlangga, 2009.

[16] H. Setiawati, A.D. Corebima, Empowering Critical Thinking Skills of The Students Having Different Academic Ability in Biology Learning of Senior High School through PQ4R - TPS
Strategy, The International Journal of Social Sciences and Humanities Invention 4(5) (2017) 3521-3526.

DOI: https://doi.org/10.18535/ijsshi/v4i5.09

[17] L. Margaret, N. Bahr, Thinking Critically about Critical Thinking in Higher Education, International Journal for the Scholarship of Teaching and Learning 4(2) (2010) 1-17. DOI: https://doi.org/10.20429/ijsotl.2010.040209

[18] W. Insih, Senam, I. Suryani, Analysis of junior high school student's critical thinking skills integrated with the local potential of eremerasa nature tourism, in: AIP Conference Proceeding, vol. 1440, American Institute of Physics, Maryland, 2020, pp. 1-6. DOI: https://doi.org/10.1088/17426596/1440/1/012096

[19] K.S. Taber, Modeling Students and Learning in Science Education, Developing Respresentation of Concepts, Conceptual Structure and Conceptual Change to Inform Teaching and Research, 2013.2 DOI: https://doi.org/10.1007/978-94-007-7648-7

[20] OECD, PISA 2015 Result in Focus, OECD Publishing, 2016.

[21] C.S.K. Wah, et. al, 21st Century Skills Development through Inquiry-Based Learning from Theory to Practice, Springer, 2017.

[22] N.W.R. Lestari, I.W. Sadia, K. Sema, The Effect of Experiential Learning Model on Students' Critical Thinking Skills and Motivation. EJournal Program Pascasarjana Universitas Pendidikan Ganesha 4(1) (2014) 1-10.

[23] F. Daud, I. Hafsari, The Contribution of Critical Thinking Skills and Metacognitive Awareness on Students' Learning: Teaching Biology at Senior High School, Modern Applied Science 9(12) (2015) 143-153. DOI: https://doi.org/10.5539/mas.v9n12p143

[24] Y. Hidayati, P. Sinaga, The profile of critical thinking skills students on science learning, in: AIP Conference Proceeding, vol. 1402, American Institute of Physics, Maryland, 2019, pp. 12-22. DOI: https://doi.org/10.1088/1742$\underline{6596 / 1402 / 4 / 044075}$

[25] T. Thomas, Developing First Year Students Critical Thinking Skills, Asian Social Science Journal 7(4) (2011) 26-35. DOI: https://doi.org/ 10.5539/ass.v7n4p26 
[26] S. Bell, Project-Based Learning for the 21st Century: Skill for the Future, The Clearing House 83(2) (2010) 30-43. DOI: https://doi.org/10.1080/00098650903505415

[27] D. Kuhn, A Developmental Model of Critical Thinking, Educational Researcher 28(2) (1999) 16-26.

DOI:

https://doi.org/10.3102/0013189X028002016

[28] C. Chaiyasut, R. Samuttai, S. Phuwiphadawa, N. Inthanet, Factors and Indicators of Teachers' Roles that Promote Lifelong Learning Skills of Students at The Basic Education Level, International Journal of Behavioral Science 9(2) (2014) 71-86. DOI: https://doi.org/10.14456/ijbs.2014.6

[29] K. Changwong, A. Sukkamart, B. Sisan, Critical Thinking Skill Development: Analysis of A New Learning Management Model for Thai High Schools, Journal of International Studies 11(2) (2018) 37-48. DOI: https://doi.org/10.14254/2071- 8330.2018/11-2/3

[30] E.M. Reeve, 21st-Century Skills Needed by Students in Technical and Vocational Education and Training (TVET), Asian International Journal of Social Sciences 16(4) (2016) 65-82. https://doi.org/10.29139/aijss.20160404

[31] K. Hayes, A. Devitt, Classroom Discussions with Student-Led Feedback: A Useful Activity to Enhance Development of Critical Thinking Skills, Journal of Food Science Education 7(4) (2008) 65-68. DOI: https://doi.org/10.1111/j.15414329.2008.00054.x

[32] K. Changwong, A. Sukkamart, B. Sisan, Critical Thinking Skill Development: Analysis of A New Learning Management Model for Thai High Schools, Journal of International Studies 11(2) (2018) 37-48. DOI: https://doi.org/ $\underline{10.14254 / 2071-8330.2018 / 11-2 / 3}$

[33] National Education Standards Agency, 21st Century Education Paradigm Development, National Education Standards Agency, 2010.

[34] I.J. Quitadamo, C.L. Faiola, J.E. Johnson, M.J. Kurtz, Community-Based Inquiry Improves Critical Thinking in General Education Biology, Life Science Education Journal 7 (2008) 327337. DOI: https://doi.org/10.1187/cbe.07-110097 